\title{
Recombinant fusion protein by lysozyme and antibacterial peptide enhances ischemic wound healing via angiogenesis and reduction of inflammation in diabetic $d b / d b$ mice
}

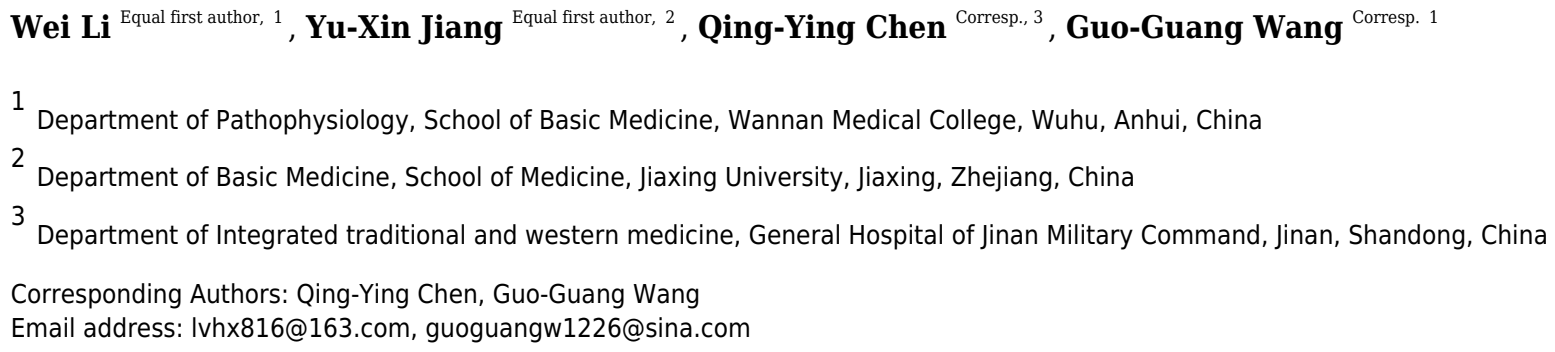

Background \& aims. Lysozyme and antibacterial peptides have been reported to broadspectrum antibacterial activity and can further improve wound healing. The aim of this study was to assess the effectiveness of a recombinant fusion protein created by combining lysozyme and an antibacterial peptide in forming new vessels and wound healing in an ischemic hind limb. Methods. An ischemic hind limb model was established by isolation and ligation of the femoral artery in diabetic $d b / d b$ mice. Cutaneous wounds were created with or without ischemia. Adductor muscles and wounds were treated with or without the fusion protein. Results. The fusion protein accelerated ischemic diabetic wound healing and attenuated impairment of ischemic adductor muscle . Further, the fusion protein elevated expression of platelet derived growth factor (PDGF) and vascular endothelial growth factor (VEGF) protein and mRNA in ischemic adductor muscle, reduced levels of tumor necrosis factor-alpha (TNF- $\alpha$ ) and interleukin-6 (IL-6) in serum and expression of phosphorylated nuclear factor $\mathrm{KB}$ ( $\mathrm{p}-\mathrm{NF}-\mathrm{KB}$ ) and $\mathrm{p}-\mathrm{IKB} \alpha$ in ischemic adductor. The fusion protein also enhanced levels of phosphorylated VEGF and PDGF receptors in the ischemic adductor muscles from diabetic $d b / d b$ mice. Conclusion. The data showed that the beneficial effects of the fusion protein on ischemic wound healing may be associated with angiogenesis and reduction of inflammatory response in the ischemic adductor muscles of diabetic $d b / d b$ mice. 
1 Title:

2 Recombinant fusion protein by lysozyme and antibacterial peptide enhances ischemic wound

3 healing via angiogenesis and reduction of inflammation in diabetic $\mathrm{db} / \mathrm{db}$ mice

\section{Author names and affiliations}

6 Wei $\mathrm{Li}^{1 *}$, Yu-Xin Jiang ${ }^{2 *}$, Qing-Ying Chen ${ }^{3 \#}$, Guo-Guang Wang ${ }^{1 \#}$

$7{ }^{1}$ Department of Pathophysiology, School of Basic Medicine, Wannan Medical College, Wuhu 241000, China.

$8 \quad 2$ Department of Basic Medicine, School of Medicine, Jiaxing University, Jiaxing 314001, China.

$9{ }^{3}$ Department of Integrated traditional and western medicine, General Hospital of Jinan Military Command, 10 Jinan, 250031, China.

$11 *$ These authors contributed equally to this work.

12 \# These authors are both corresponding authors.

\section{Corresponding Authors}

14 1. Qing-Ying Chen

15 Postal address: No. 25 Shifan Road, Jinan, Shandong Province, China

16 Email: vhx816@163.com

17 2. Guoguang Wang

18 Postal address: No. 22, West of Wenchang Road, Yijiang District, Anhui Province, China

19 Email: guoguangw1226@sina.com 


\section{ABSTRACT}

Background \& aims. Lysozyme and antibacterial peptides have been reported to possess broad-spectrum antibacterial activity and can further improve wound healing. The aim of this study was to assess the effectiveness of a recombinant fusion protein created by combining lysozyme and an antibacterial peptide in forming new vessels and wound healing in an ischemic hind limb.

Methods. An ischemic hind limb model was established by isolation and ligation of the femoral artery in diabetic mice. Cutaneous wounds were created with or without ischemia. Adductor muscles and wounds were treated with or without the fusion protein.

Results. The fusion protein treatment accelerated ischemic diabetic wound healing and attenuated impairment of ischemic adductor muscle. Furthermore, the fusion protein elevated expression of platelet derived growth factor (PDGF) and vascular endothelial growth factor (VEGF) protein and mRNA in the ischemic adductor muscle, reduced levels of tumor necrosis factor-alpha (TNF- $\alpha$ ) and interleukin-6 (IL-6) in serum and expression of phosphorylated nuclear factor $\kappa \mathrm{B}(\mathrm{p}-\mathrm{NF}-\kappa \mathrm{B})$ and phosphorylated inhibitor of NF- $\mathrm{B}$ (p-IKB) $\alpha$ in the ischemic adductor. The fusion protein also enhanced levels of phosphorylated VEGF and PDGF receptors in the ischemic adductor muscles from diabetic $\mathrm{db} / \mathrm{db}$ mice.

Conclusion. The data show that the beneficial effects of the fusion protein on ischemic wound healing may be associated with angiogenesis and reduction of inflammatory response in the ischemic adductor muscles of diabetic $\mathrm{db} / \mathrm{db}$ mice.

Keywords: Diabetes, ischemia, wound healing, lysozyme, antibacterial peptide, fusion protein

\section{Abbreviations:}

BCA, bicinchoninic acid; DAB, 3,3'-diaminobenzidine; eNOS, endothelial nitric oxide synthase; IKB $\alpha$, inhibitor of NF kappa B alpha; FGF, fibroblast growth factor; HIF, hypoxia inducible factor; IL-6, interleukin6; NF- $\mathrm{B}$, nuclear factor-kappa B; PBS, phosphate buffered saline; PDGF, platelet derived growth factor; PDGFR, PDGF receptor; TNF- $\alpha$, tumor necrosis factor-alpha; VEGF, vascular endothelial growth factor; VEGFR, VEGF receptor. 


\section{INTRODUCTION}

Vascular disease is a severe complication of diabetes, in addition to being a major cause of mortality and morbidity in diabetic patients. Such complications can result in damage to a number of important organs such as the heart, kidneys and retinas (Srikanth \& Deedwania 2011). Although the mechanisms responsible for vascular disease in diabetics remain unclear, results from numerous studies suggest that decreased expression of critical growth factors resulting from hyperglycemia can play a vital role in these diabetic vascular complications (Schratzberger et al. 2001). It is widely known that diabetes can cause peripheral vasculopathy and microcirculatory disturbance which contributes to ischemia in the lower limbs of patients with diabetes. Ischemia results in patients being prone to the formation of diabetic foot ulcers, exacerbating existing ulcers, and delaying diabetic wound healing (Lobmann et al. 2002). Thus, peripheral vasculopathy increases the risk of lower limb amputation in cases of diabetic ulcer (Deshpande et al. 2008). Various studies have suggested that growth factors such as vascular endothelial growth factor (VEGF) and platelet-derived growth factor (PDGF) can accelerate wound healing by increasing vessel formation ( $\mathrm{Li}$ et al. 2008). In addition, clinical and experimental studies have indicated that cell transplantation can improve wound healing by accelerating the formation of blood vessels (Amann et al. 2009).

Lysozyme, a ubiquitous basic hydrolase in animals and plants, is an antibacterial enzyme which can kill many bacteria by hydrolyzing peptidoglycans in the bacterial cell wall (Callewaert \& Michiels 2010). Therefore, lysozyme is regarded as a key component of the innate immune system. It is expressed in macrophages and secreted into a number of body fluids, preventing infection from pathogenic bacteria and viruses within wounds and fractures in trauma patients (Banks et al. 1986; Callewaert \& Michiels 2010). Many studies have confirmed that lysozyme exhibits, as a non-specific immune factor, a variety of biological functions such as regulation of the function and proliferation of polymorphonuclear neutrophils and phagocytes, anti-tumor activity (Royet et al. 2011), increased angiogenesis (Nakatsuji \& Gallo 2012) and wound healing, and downregulation of an inflammatory response in a number of scenarios (Markart et al. 2004).

Antibacterial peptides are part of a class of small molecular peptides with broad-spectrum antibacterial activity, an important defense system of a host against bacteria, fungi and some viruses (Hilchie et al. 2013). These peptides are widely found in insects and mammals as important molecular barriers in the host defense 
77

against invasion from pathogenic microorganisms (Bellm et al. 2000). Cecropin B is an antibacterial peptide with selective toxicity and is a broad spectrum antimicrobial which is widely found in the insects Drosophila melanogaster and hyalophora (Seshadri Sundararajan et al. 2012). In addition, a number of studies have indicated that some antibacterial peptides, including cecropins, possess anti-cancer activity (Hilchie et al. 2011), exhibit anti-inflammatory effects and promote wound healing (Feng et al. 2012).

Antibacterial peptides and lysozyme are easily degraded and so they are expressed at physiologically low concentrations. Therefore, to create a synergistic effect between antibacterial peptides and lysozyme and enhance their stability and expression, a fusion protein was constructed from the two through gene recombination. It has been reported previously that fusion proteins created from antibacterial peptides and lysozyme can improve wound healing (Koczulla \& Bals 2003).

Individuals with diabetic vasculopathy face considerable health risks from diabetic foot ulcers and delayed wound healing. Thus, the aim of the present study was to establish a diabetic type 2 diabetes mouse model $(d b / d b)$ with marked hyperglycemia and vascular complications to investigate the mechanisms of action of a fusion protein on angiogenesis and wound healing in the hind limbs in which ischemia has been induced.

\section{MATERIALS \& METHODS}

\section{Reagents and antibodies}

Rabbit polyclonal antibodies towards $\beta$-actin, PDGF receptor (PDGFR) $\beta$, p-PDGFR $\beta$, VEGF, VEGF receptor

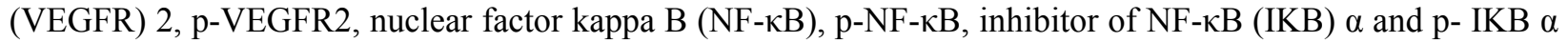
were purchased from Santa Cruz Biotechnology (USA). Pentobarbital sodium and horseradish peroxidaseconjugated secondary goat anti-rabbit antibody were purchased from Sigma (Sigma Chemical Co., St. Louis, MO, USA).

\section{Fusion protein}

The fusion protein spray was purchased from Huaibei Shangyi Biotechnology Co., Ltd (Anhui, China). The fusion protein gene was constructed from chicken lysozyme and antibacterial peptide from Drosophila melanogaster, and then expressed in E. coli BL21 (DE3). 


\section{Animal}

Forty male type 2 diabetic $d b / d b$ mice ( $8-10$ weeks of age) were purchased from Shanghai Laboratory Animal Co. (SLAC), Ltd (Shanghai, China), and acclimatized in the animal facility with a $12 \mathrm{~h}$ day/night cycle, controlled temperature of $22 \pm 2{ }^{\circ} \mathrm{C}$ and $55 \% \pm 15 \%$ humidity for two weeks prior to experimentation. This project is conducted in accordance with the National Institutes of Health Guide for the Care and Use of Laboratory Animals by Animal Experimental Ethics Committee of Wannan Medical College (20180311).

\section{Experimental design}

Animals were randomly assigned to four groups (10 mice per group): non-ischemia control (NONISCH), nonischemia plus administration of protein (NONISCH+PROT), ischemia control (ISCH) and ischemia plus administration of protein (ISCH+PROT). The mice were anaesthetized with $1.5 \%$ pentobarbital sodium $(45 \mathrm{mg} / \mathrm{kg})$ by intraperitoneal injection. A small incision was created and the femoral artery exposed and separated, then ligated for induction of hind limb ischemia in the corresponding group of animals. The $\mathrm{NONISCH}+\mathrm{PROT}$ and ISCH+PROT mice were injected with fusion protein $(0.1 \mathrm{~mL}, 50 \mu \mathrm{g} / \mathrm{mL})$ in the quadriceps and gastrocnemius. A round, full-thickness skin excision (6 $\mathrm{mm}$ in diameter) was created dorsally. After washed with normal saline, excisions from the NONISCH+PROT and ISCH+PROT mice were sprayed with fusion protein twice per day for 14 days. The wound areas were assessed via marking on the transparent tracing sheet along edge of the wound and analyzed by Image J software (NIH, USA). At the end of the experiment, mice were anaesthetized with pentobarbital sodium and the carotid artery was separated for collection of blood sample via cannulation. After the mice were euthanized via bleeding, abductor muscles and granulation tissue were harvested, half of these were fixed in $4 \%$ neutral formalin for histological analysis, meanwhile the remaining tissues were stored at $-80^{\circ} \mathrm{C}$ until use.

\section{Enzyme-Linked Immunosorbent Assay (ELISA)}

Blood samples were collected to quantify proangiogenic factors in serum. The concentrations of VEGF and PDGF were determined using VEGF and PDGF-specific ELISA kits (Hefei Bomei Biotechnology Co., Ltd, China). The concentrations of VEGF and PDGF were expressed as $\mathrm{ng} / \mathrm{L}$ and $\mathrm{pg} / \mathrm{mL}$, respectively. Wound samples were homogenized in cold phosphate buffered saline (PBS) and centrifuged at $10000 \diamond \mathrm{g}$ and $4^{\circ} \mathrm{C}$ for $20 \mathrm{~min}$. The supernatants were used to determine inflammatory cytokines such as TNF- $\alpha$ and IL-6 using 
131

132

133

134

135

136

137

138

139

140

141

142

143

144

145

146

147

148

149

150

151

152

153

154

155

156

157

ELISA kits.

\section{Histopathology}

Abductor muscles and granulation tissue were harvested and fixed in $4 \%$ formalin, then embedded in paraffin.

The embedded samples were then cut into $5 \mu \mathrm{m}$ thick sections and stained with hematoxylin and eosin (HE) to assess the inflammatory infiltrate and Masson's trichrome to measure the area of collagen within the matrix and thickness of granulation tissue.

\section{Immunohistochemistry}

Immunohistochemistry of tissues was performed as previously describe ( $\mathrm{Li}$ et al. 2015). Fixed specimens were embedded in paraffin and then cut into $5 \mu \mathrm{m}$ thick sections. After 2 hours of baking and deparaffinization, sections were treated with ethylenediamine tetraacetic acid (EDTA) buffer for antigenic retrieval, followed by incubation in hydrogen peroxide in methanol for inhibition of endogenous peroxidase. The sections were then incubated with bovine serum albumin to prevent non-specific binding. The sections were incubated with PDGF or CD34 primary antibodies (Santa Cruz Biotechnology, USA) overnight at $4^{\circ} \mathrm{C}$, rinsed with PBS and then incubated with biotin-conjugated secondary antibody. After washing, the sections were incubated with streptavidin-horseradish peroxidase. The sections were embedded in 3,3'-diaminobenzidine (DAB), and counterstained with hematoxylin then mounted prior to viewing.

\section{Real-time polymerase chain reaction (RT-PCR)}

RT-PCR was performed to measure mRNA levels of VEGF, PDGF, hypoxia inducible factor (HIF)-1 $\alpha$, fibroblast growth factor (FGF) 2 and endothelial nitric oxide synthase (eNOS). Total RNA was extracted from the adductor muscles with Trizol reagent. mRNA was utilized to synthesize cDNA by superscript II reverse transcriptase. RT-PCR was performed by SYBR Green Real-time PCR Master Mix on an iCycler machine (BioRad) to amplify cDNA according to the manufacturer's instructions. The expression of gene mRNA was normalized with the housekeeping gene $\beta$-actin. Relative changes in gene expression were analyzed using the $2^{-}$ ${ }^{\Delta \Delta C T}$ method (Livak \& Schmittgen 2001). Sequence primers for PCR:

VEGF (F: 5'-CACAGCAGATGTGAATGCAG-3', R: 5'-TTTACACGTCTGCGGATCTT-3')

PDGF (F: 5'-CTCTTGGAGATAGACTCCGTAGG-3', R: 5'-ACTTCTCTTCCTGCGAATGG-3')

HIF-1 $\alpha$ (F: 5'-GGGTACAAGAAACCACCCAT-3', R: 5'-GAGGCTGTGTCGACTGAGAA-3')

Peer] reviewing PDF | (2020:09:53150:2:0:NEW 15 Feb 2021) 
FGF2 (F: 5'-CAACCGGTACCTTGCTATGA-3', R: 5'-TCCGTGACCGGTAAGTATTG-3') eNOS (F: 5'- CCTTCCGCTACCAGCCAGA-3', R: 5'-CAGAGATCTTCACTGCATTGGCTA-3') ACTB (F: 5’-AGTGTGACGTTGACATCCGT-3', R: TGCTAGGAGCCAGAGCAGTA-3’).

\section{Western blotting}

Adductor muscles were lysed in lysis buffer $(50 \mathrm{mmol} / \mathrm{L}$ HEPES, $100 \mathrm{mmol} / \mathrm{L}$ sodium fluoride, $100 \mathrm{mmol} / \mathrm{L}$ sodium pyrophosphate, $1 \%$ Triton-X 100) containing $10 \mathrm{mmol} / \mathrm{L}$ sodium orthovanadate, $2 \mathrm{mmol} / \mathrm{L}$ phenyl methylsulfonyl fluoride and protease inhibitors $(10 \mu \mathrm{g} / \mathrm{L}$ leupeptin and aprotinin). The protein in the lysate was quantified using a bicinchoninic acid (BCA) kit (Bio-Rad). The lysates were electrophoretically separated using $10 \%$ SDS-PAGE and then transferred to nitrocellulose membranes. The membranes were blocked with $5 \%$ skimmed milk, and then incubated with anti $\beta$-actin, PDGFR $\beta$, p-PDGFR $\beta$, VEGF, VEGFR2, p-VEGFR2, NF$\kappa \mathrm{B}, \mathrm{p}-\mathrm{NF}-\kappa \mathrm{B}, \mathrm{IKB} \alpha$ and $\mathrm{p}-\mathrm{IKB} \alpha(1: 1000)$ antibodies, respectively. Antigens were detected and visualized using DAB.

\section{Statistical analysis}

Values are presented as means \pm standard deviation (SD) for each group. Statistical analysis was performed using an unpaired Student $t$ test or one-way analysis of variance (ANOVA) and corrected using a Bonferroni/Dunn test. $\mathrm{P}<0.05$ was considered statistically significant. Analysis was performed using SPSS v18.0 software (SPSS Inc., Chicago, IL, USA).

\section{RESULTS}

\section{Effects of the fusion protein on ischemic wound healing}

At the beginning, the wounds of every rat were swelling and purulent, but closure of the ischemic wound was slower than that of the nonischemic wound, and the fusion protein treatment enhanced wound healing compared with ischemic wound (Fig. 1E). Wound sections stained with HE exhibited the reduction of inflammatory cell infiltration and increase of the number of blood vessels in the ischemic wound treated with the fusion protein compared with the ISCH (Figs. 1B and 1C). Hair follicles and stratified epithelium were observed within the wound sections of ischemic mice treated with the fusion protein (Figs. 1B and 1C). 
185

186

187

188

189

190

191

192

193

194

196

197

198

199

200

201

202

203

204

205

206

207

208

209

210

211

Collagen fibers play an important role in wound healing. In this study, collagen fibers were determined with masson's trichrome staining, and the results show that collagen fibers were reduced in the ischemic diabetic wound compared with the non-ischemic wound (Fig. 1A), and collagen fibers were clearer and more regular arranged in ischemic wound treated with the fusion protein compared with the ISCH (Fig. 1A).

Furthermore, immunohistochemical staining with Caspase 3 show that the fusion protein decreased expression of Caspase 3 (Fig. 1D)

\section{Effects of the fusion protein on Inflammatory Markers}

Our results indicate that ischemia of the adductor muscle significantly increased levels of TNF- $\alpha$ and IL-6 compared with the NONISCH $(\mathrm{p}<0.05)$ (Figs. $2 \mathrm{~A}$ and $2 \mathrm{~B})$. Conversely, treatment with fusion protein reduced levels of NF- $\alpha$ and IL-6 in the ischemic wound when compared with the ISCH group $(\mathrm{p}<0.05)$ (Figs. 2A and 2B). But there was no significant difference in levels of NF- $\alpha$ and IL-6 between the NONISCH and the NONISCH+PROT groups ( $>0.05$ ) (Figs. 2A and 2B).

\section{Effects of the fusion protein on proangiogenic growth factor}

Proangiogenic growth factors including PDGF and VEGF have been confirmed to accelerate wound closure via angiogenesis. Our results show that ischemia decreased serum levels of PDGF and VEGF compared with the NONISH group $(\mathrm{P}<0.05)$ (Figs. 3A and 3B). However, the fusion protein elevated the levels of PDGF and VEGF in serum $(\mathbf{P}<\mathbf{0 . 0 1})$ (Figs. 3A and 3B).

\section{Effects of the fusion protein on ischemic adductor muscle}

Improvement of blood supply in adductor muscles plays a vital role in wound closure of ischemic lower limb. Therefore, we investigated the effect of the fusion protein on the ischemic adductor muscles. Examination of HE sections show that impaired adductor muscle was observed in ischemic lower limb. Conversely, the fusion protein attenuated impairment of ischemic adductor muscle (Figs. 4A and 4B) and increased the number of capillaries compared with the ISCH group $(\mathrm{p}<0.05)$ ( Fig. 4F). Furthermore, immunohistochemical staining was used to observe proangiogenic growth factor and marker of angiogenesis. The results show that the fusion protein 
212 treatment enhanced expression of CD34 and PDGF in ischemic adductor muscle compared to the ISCH group

213 (Figs. 4C and 4D) and reduced expression of Caspase 3 (Fig. 4E), suggesting that improvement of ischemic

214 wound healing was associated with angiogenesis.

215

216 Effects of the fusion protein on mRNA expression of proangiogenic growth factors

217 To explore improvements in wound healing due to the fusion protein in diabetic ischemic limbs, we quantified

218 the expression of proangiogenic growth factor genes and protein. The results of RT-PCR analysis demonstrate

219 that the expression of VEGF and PDGF mRNA decreased significantly in the adductor muscles of ischemic

220 limbs compared with their expression in non-ischemic limbs $(\mathrm{P}<0.05)$ (Figs. 5A and 5B). Moreover, ischemia

221 also resulted in decreased expression of FGF-2, eNOS and HIF-1 $\alpha$ mRNA in the adductor muscles $(\mathrm{P}<0.05)$

222 (Figs. 5C-5E). Treatment using fusion protein increased expression of these growth factors in the muscles of ischemic limbs when compared with the ISCH group $(\mathrm{P}<0.05)$ (Figs. 5A-5E).

Effects of the fusion protein on expression of proangiogenic growth factor in ischemic adductor muscles

In this study, we further examined changes of VEGF and PDGF protein expression in the ischemic adductor muscles. The expression of VEGF and PDGF protein decreased in the adductor muscles of ischemic limbs compared with non-ischemic limbs, while ischemia resulted in decreased phosphorylation of their respective receptors VEGFR2 and PDGFR- $\beta$. Treatment with fusion protein increased phosphorylation of PDGFR- $\beta$ $(\mathrm{P}<0.05)$ (Figs. 6A and 6C) and VEGFR2 ( $\mathrm{P}<0.05)$ (Figs. 6B and 6D), and expression of PDGF $(\mathrm{P}<0.05)$ (Fig. 6E) and VEGF proteins compared with the ISCH group $(\mathrm{P}<0.05)$ (Fig. 6F).

\section{Effects of the fusion protein on NF-кB pathway}

$\mathrm{NF}-\mathrm{\kappa B}$ is a pivotal transcriptional factor to modulate inflammatory response. Inflammation is involved in wound (Figs. 7A-7D). 


\section{DISCUSSION}

241

242

243

244

245

246

247

248

249

250

251

252

253

254

255

256

257

258

259

260

261

262

263

264

265

In this study, our results suggest that the fusion protein accelerated ischemic wound healing and attenuated impairment of ischemic adductor muscle. Furthermore, the fusion protein enhanced the expression of the proangiogenic factors VEGF and PDGF, and levels of phosphorylated VEGFR and PDGFR. The fusion protein treatment was also observed to decrease levels of TNF- $\alpha$ and IL-6, and expression of p-NF- $\mathrm{BB}$ and p-IKB $\alpha$. These findings suggest that the fusion protein exhibited its beneficial effects via improvement of angiogenesis and modulatory effects on inflammation.

Wound healing is a complex pathophysiological process, in which various precise mechanisms including the simultaneous actions of numerous cell types and modulators are required. The impairment of wound healing due to diabetes can be attributed to ischemia, so diabetic foot ulcers have become among the most dreaded complication of diabetes because of the high risk of amputation (Marrotte et al. 2010). Ischemia aggravates diabetic macro-angiopathy and reduces re-vascularization, postponing the development of granulation tissue and re-endothelialization (Blakytny \& Jude 2006). Lysozyme and antimicrobial peptides are regarded as host defense molecules owing to their antimicrobial role, but they are also involved in host physiological functions including inflammation and wound healing (Nakatsuji \& Gallo 2012). Cathelicidin, an antimicrobial peptide, has been reported to possess antifungal and antiviral properties (Tsai et al. 2014). Further study has shown that it promotes cutaneous wound repair through enhancement of re-epithelialization (Heilborn et al. 2003). Therefore, we explored the effect of the fusion protein on the healing of ischemic wounds in diabetic mice. In this study, we observed that damage in hind limb muscles was more severe in ischemic diabetic mice than those that had normal levels of oxygenation, with ischemia reducing re-endothelialization and wound healing. Treatment with the fusion protein enhanced the healing of diabetic ischemic and non-ischemic wounds. Morphological characteristics caused by diabetes and ischemia, such as thinner granulation tissue and a degraded capillary network, were reversed. In addition, the fusion protein reduced the expression of Caspase 3 in the wounds.

Angiogenesis increases the supply of oxygen and nutrients to wounds. Therefore, it is beneficial for the formation of granulation tissue and re-epithelialization in wounds, further promoting wound healing. Angiopathy and reduced revascularization caused by a sustained lack of oxygen and nutrients due to ischemia, play important 
266

267

268

269

270

271

272

273

274

275

276

277

278

279

280

281

282

283

roles in the lack of healing in diabetic wounds (Gershater et al. 2009). Various studies suggest that increased angiogenesis promotes diabetic wound closure and neo-granulation tissue formation. It is well-known that proangiogenic factors such as VEGF and PDGF contribute to angiogenesis by inhibiting apoptosis and promoting cell proliferation, motility and survival (Roskoski 2008). A reduction in VEGF in diabetes impairs angiogenesis, resulting in ischemic arterial morbidities (Tchaikovski et al. 2009). Several studies have indicated that therapies with VEGF and PDGF increase vascularization in diabetic wounds and accelerate diabetic wound healing (Tchaikovski et al. 2009). Overexpression of VEGF is reported to improve angiogenesis and blood perfusion in the ischemic hind limbs of mice ( $\mathrm{Li}$ et al. 2015), and treatment with a combination of AMD3100 and PDGF-BB promotes neovascularization in diabetic wounds, and accelerates wound closure (Allen et al. 2014). Here, our results demonstrate that expression of VEGF and PDGF was significantly reduced in the muscles of ischemic diabetic limbs compared with normally-oxygenated limbs. Ischemia also increased the number of apoptotic cells. The fusion protein increased the expression of VEGF and PDGF.

Proangiogenic factors are involved in angiogenesis and accelerate wound healing, but other studies have suggested that impairment of their signaling rather than their expression reduces angiogenesis and delays diabetic wound healing (Geraldes et al. 2009). Therefore, enhancing the signaling related to angiogenesis may be beneficial to diabetic wound healing. Diabetes disrupts VEGF and PDGF signaling via reduced activation of VEGF and PDGF receptors, Akt and ERK, etc (Lizotte et al. 2013). HIF-1 $\alpha$ is a vital cytokine which regulates angiogenesis in hypoxic tissue. Treatment with HIF-1 $\alpha$ increases vessel density and improves limb perfusion (Sarkar et al. 2009). Our results indicate that expression of VEGF, PDGF and eNOS mRNA in ischemic limbs decreased in diabetic mice. Treatment with the fusion protein restored expression of these growth factors, enhanced phosphorylation of VEGFR and PDGFR, and increased capillary density in ischemic limbs. Treatment with the fusion protein also increased expression of HIF-1 $\alpha$. Similarly, the number of capillaries in the granulation tissue also increased. Therefore, these results suggest that the fusion protein accelerated wound healing via increased VEGF and PDGF signaling.

Inflammation is a vital factor in cutaneous wound closure, and gradually subsides in the next five days (Eming et al. 2007). Hyperglycemia causes oxidative stress through diverse mechanisms such as glucose autooxidation, the polyol and hexosamine pathways and advanced glycosylation end products (Evans et al. 2003; 
293 Nishikawa et al. 2000). Oxidative stress triggers persistence of inflammatory response, inflammation is one of 294 the most important mechanisms in diabetic complications including the delayed wound healing (Soneja et al. 295 2005). It has been reported that excessive generation of proinflammatory cytokines such as TNF- $\alpha$ and IL-6 296 delays diabetic wound healing (Fahey et al. 1991; Guo et al. 2007; Haidara et al. 2009). Nuclear factor kappa B 297 (NF-kB) is a vital transcription factor that plays an important role in various biological processes such as 298 apoptosis, migration, cell proliferation and inflammation (Ghosh \& Karin 2002; Hoesel \& Schmid 2013; 299 Monkkonen \& Debnath 2018). Furthermore, NF-kB has been reported to be involved in the pathogenesis of several chronic diseases (Sanchez \& Sharma 2009; Wullaert et al. 2011). IKB $\alpha$ regulates activation of NF-KB via phosphorylation and degradation, phosphorylated $\mathrm{IKB} \alpha$ activates NF- $\mathrm{KB}$. Activated NF- $\mathrm{BB}$ translocates to the nucleus, binds to DNA and accelerates the transcription of proinflammatory cytokines and enzymes including IL-6, TNF- $\alpha$, and iNOS (Kim et al. 2010; Li et al. 2010; Tak \& Firestein 2001). Sustained hyperglycemia is confirmed to result in abnormal activation of NF- $\mathrm{BB}$ in type 1 diabetes, which contributes inflammatory response and oxidative stress (Giacco \& Brownlee 2010). Pharmacologic research suggests that inhibited NF- $\mathrm{B}$ ameliorates diabetic vascular function (Kassan et al. 2013). Activated NF- $\mathrm{KB}$ has reported to be involved in diabetic complications in various cell types (Suryavanshi \& Kulkarni 2017). Recent study has demonstrated that $\mathrm{NF}-\kappa \mathrm{B} / \mathrm{IKB} \alpha$ signaling pathway is upregulated in diabetic wound, and downregulation of $\mathrm{NF}-\kappa \mathrm{B} / \mathrm{IKB} \alpha$ signaling pathway improves diabetic wound healing (Yuan et al. 2018). Our data show that the fusion protein reduced levels of TNF- $\alpha$ and IL-6, downregulated NF- $\mathrm{KB} / \mathrm{IKB} \alpha$ signaling pathway in ischemic diabetic wound. These exhibit anti-inflammation of the fusion protein in ischemic diabetic wound.

\section{CONCLUSIONS}

In summary, the present study indicates that the fusion protein promotes ischemic diabetic wound closure, alleviates damage of ischemic adductor muscles in diabetic mice. These positive effects are associated with acceleration of angiogenesis and decrease of inflammation. Therefore, the fusion protein may be an effective therapeutic drug against diabetic foot ulcers.

\section{Funding}


320

321

322

323

324

325

326

327

328

329

330

331

332

333

334

335

336

337

338

339

340

341

342

343

344

345

346

This study was supported by grants from the Army Key Project (No. BJN14C001), the National Natural Science Foundation of China (No. 811-72790, and No. 81671586), the Academic and Technical Leaders of Wannan Medical College (No. 010202041703), and University Outstanding Young Talents Project of Anhui Province (No. gxyq2017036).

\section{Competing Interests}

The authors declare there are no competing interests.

\section{Author Contributions}

- Wei Li conceived and designed the experiments, performed the experiments, prepared figures and/or tables, and approved the final draft.

- Yu-Xin Jiang performed the experiments, prepared figures and/or tables, reviewed drafts of the paper, and approved the final draft.

- Qing-Ying Chen performed the experiments, authored or reviewed drafts of the paper, and approved the final draft.

- Guo-Guang Wang analyzed the data, authored or reviewed drafts of the paper, prepared figures and/or tables, and approved the final draft.

\section{Animal Ethics}

The following information was supplied relating to ethical approvals (i.e., approving body and any reference numbers):

All experimental projects were reviewed and approved by Animal Experimental Ethics Committee of Wannan Medical College (No. 20180311).

\section{Data Availability}

The following information was supplied regarding data availability:

The raw data are available in the Supplementary Files. 


\section{References:}

Allen RJ, Jr., Soares MA, Haberman ID, Szpalski C, Schachar J, Lin CD, Nguyen PD, Saadeh PB, and Warren SM. 2014. Combination therapy accelerates diabetic wound closure. PLoS One 9:e92667. 10.1371/journal.pone.0092667

Amann B, Luedemann C, Ratei R, and Schmidt-Lucke JA. 2009. Autologous bone marrow cell transplantation increases leg perfusion and reduces amputations in patients with advanced critical limb ischemia due to peripheral artery disease. Cell Transplant 18:371-380. 10.3727/096368909788534942

Banks JG, Board RG, and Sparks NH. 1986. Natural antimicrobial systems and their potential in food preservation of the future. Biotechnol Appl Biochem 8:103-147.

Bellm L, Lehrer RI, and Ganz T. 2000. Protegrins: new antibiotics of mammalian origin. Expert Opin Investig Drugs 9:1731-1742. 10.1517/13543784.9.8.1731

Blakytny R, and Jude E. 2006. The molecular biology of chronic wounds and delayed healing in diabetes. Diabet Med 23:594-608. 10.1111/j.1464-5491.2006.01773.x

Callewaert L, and Michiels CW. 2010. Lysozymes in the animal kingdom. J Biosci 35:127-160. 10.1007/s12038-0100015-5

Deshpande AD, Harris-Hayes M, and Schootman M. 2008. Epidemiology of diabetes and diabetes-related complications. Phys Ther 88:1254-1264. 10.2522/ptj.20080020

Eming SA, Krieg T, and Davidson JM. 2007. Inflammation in wound repair: molecular and cellular mechanisms. $J$ Invest Dermatol 127:514-525. 10.1038/sj.jid.5700701

Evans JL, Goldfine ID, Maddux BA, and Grodsky GM. 2003. Are oxidative stress-activated signaling pathways mediators of insulin resistance and beta-cell dysfunction? Diabetes 52:1-8. 10.2337/diabetes.52.1.1

Fahey TJ, 3rd, Sadaty A, Jones WG, 2nd, Barber A, Smoller B, and Shires GT. 1991. Diabetes impairs the late inflammatory response to wound healing. J Surg Res 50:308-313. 10.1016/0022-4804(91)90196-s

Feng XL, Zhou B, Cao RB, Liu QT, Liu K, Liu XD, Zhang YP, Huang L, Ji XB, Luo J, Zhang G, and Chen PY. 2012. Immunomodulatory roles and functional analysis of pre-B lymphocyte DT40 cells with the bursal-derived BSP-II treatment. Peptides 36:292-298. 10.1016/j.peptides.2012.04.015

Geraldes P, Hiraoka-Yamamoto J, Matsumoto M, Clermont A, Leitges M, Marette A, Aiello LP, Kern TS, and King GL. 2009. Activation of PKC-delta and SHP-1 by hyperglycemia causes vascular cell apoptosis and diabetic retinopathy. Nat Med 15:1298-1306. 10.1038/nm.2052

Gershater MA, Londahl M, Nyberg P, Larsson J, Thorne J, Eneroth M, and Apelqvist J. 2009. Complexity of factors related to outcome of neuropathic and neuroischaemic/ischaemic diabetic foot ulcers: a cohort study. Diabetologia 52:398-407. 10.1007/s00125-008-1226-2

Ghosh S, and Karin M. 2002. Missing pieces in the NF-kappaB puzzle. Cell 109 Suppl:S81-96. 10.1016/s00928674(02)00703-1

Giacco F, and Brownlee M. 2010. Oxidative stress and diabetic complications. Circ Res 107:1058-1070. 10.1161/CIRCRESAHA.110.223545

Guo Z, Xia Z, Jiang J, and McNeill JH. 2007. Downregulation of NADPH oxidase, antioxidant enzymes, and inflammatory markers in the heart of streptozotocin-induced diabetic rats by N-acetyl-L-cysteine. $\mathrm{Am} \mathrm{J}$ Physiol Heart Circ Physiol 292:H1728-1736. 10.1152/ajpheart.01328.2005

Haidara MA, Mikhailidis DP, Rateb MA, Ahmed ZA, Yassin HZ, Ibrahim IM, and Rashed LA. 2009. Evaluation of 
389

390

391

392

393

394

395

396

397

398

399

400

401

402

403

404

405

406

407

408

409

410

411

412

413

414

415

416

417

418

419

420

421

422

423

424

425

426

427

428

429

the effect of oxidative stress and vitamin E supplementation on renal function in rats with streptozotocininduced Type 1 diabetes. J Diabetes Complications 23:130-136. 10.1016/j.jdiacomp.2008.02.011

Heilborn JD, Nilsson MF, Kratz G, Weber G, Sorensen O, Borregaard N, and Stahle-Backdahl M. 2003. The cathelicidin anti-microbial peptide LL-37 is involved in re-epithelialization of human skin wounds and is lacking in chronic ulcer epithelium. J Invest Dermatol 120:379-389. 10.1046/j.1523-1747.2003.12069.x

Hilchie AL, Doucette CD, Pinto DM, Patrzykat A, Douglas S, and Hoskin DW. 2011. Pleurocidin-family cationic antimicrobial peptides are cytolytic for breast carcinoma cells and prevent growth of tumor xenografts. Breast Cancer Res 13:R102. 10.1186/bcr3043

Hilchie AL, Wuerth K, and Hancock RE. 2013. Immune modulation by multifaceted cationic host defense (antimicrobial) peptides. Nat Chem Biol 9:761-768. 10.1038/nchembio.1393

Hoesel B, and Schmid JA. 2013. The complexity of NF-kappaB signaling in inflammation and cancer. Mol Cancer 12:86. 10.1186/1476-4598-12-86

Kassan M, Choi SK, Galan M, Bishop A, Umezawa K, Trebak M, Belmadani S, and Matrougui K. 2013. Enhanced NF-kappaB activity impairs vascular function through PARP-1-, SP-1-, and COX-2-dependent mechanisms in type 2 diabetes. Diabetes 62:2078-2087. 10.2337/db12-1374

Kim YS, Kim JS, Kwon JS, Jeong MH, Cho JG, Park JC, Kang JC, and Ahn Y. 2010. BAY 11-7082, a nuclear factorkappaB inhibitor, reduces inflammation and apoptosis in a rat cardiac ischemia-reperfusion injury model. Int Heart J 51:348-353. 10.1536/ihj.51.348

Koczulla AR, and Bals R. 2003. Antimicrobial peptides: current status and therapeutic potential. Drugs 63:389-406. 10.2165/00003495-200363040-00005

Li C, Yang Z, Zhai C, Qiu W, Li D, Yi Z, Wang L, Tang J, Qian M, Luo J, and Liu M. 2010. Maslinic acid potentiates the anti-tumor activity of tumor necrosis factor alpha by inhibiting NF-kappaB signaling pathway. Mol Cancer 9:73. 10.1186/1476-4598-9-73

Li H, Fu X, Zhang L, Huang Q, Wu Z, and Sun T. 2008. Research of PDGF-BB gel on the wound healing of diabetic rats and its pharmacodynamics. $J$ Surg Res 145:41-48. 10.1016/j.jss.2007.02.044

Li X, Gan K, Song G, and Wang C. 2015. VEGF gene transfected umbilical cord mesenchymal stem cells transplantation improve the lower limb vascular lesions of diabetic rats. J Diabetes Complications 29:872881. 10.1016/j.jdiacomp.2015.04.018

Livak KJ, and Schmittgen TD. 2001. Analysis of relative gene expression data using real-time quantitative PCR and the 2(-Delta Delta C(T)) Method. Methods 25:402-408. 10.1006/meth.2001.1262

Lizotte F, Pare M, Denhez B, Leitges M, Guay A, and Geraldes P. 2013. PKCdelta impaired vessel formation and angiogenic factor expression in diabetic ischemic limbs. Diabetes 62:2948-2957. 10.2337/db12-1432

Lobmann R, Ambrosch A, Schultz G, Waldmann K, Schiweck S, and Lehnert H. 2002. Expression of matrixmetalloproteinases and their inhibitors in the wounds of diabetic and non-diabetic patients. Diabetologia 45:1011-1016. 10.1007/s00125-002-0868-8

Markart P, Korfhagen TR, Weaver TE, and Akinbi HT. 2004. Mouse lysozyme M is important in pulmonary host defense against Klebsiella pneumoniae infection. Am J Respir Crit Care Med 169:454-458. 10.1164/rccm.200305-669OC

Marrotte EJ, Chen DD, Hakim JS, and Chen AF. 2010. Manganese superoxide dismutase expression in endothelial progenitor cells accelerates wound healing in diabetic mice. J Clin Invest 120:4207-4219. 10.1172/JCI36858

Monkkonen T, and Debnath J. 2018. Inflammatory signaling cascades and autophagy in cancer. Autophagy 14:190-

Peer] reviewing PDF | (2020:09:53150:2:0:NEW 15 Feb 2021) 
198. $10.1080 / 15548627.2017 .1345412$

Nakatsuji T, and Gallo RL. 2012. Antimicrobial peptides: old molecules with new ideas. J Invest Dermatol 132:887895. 10.1038/jid.2011.387

Nishikawa T, Edelstein D, Du XL, Yamagishi S, Matsumura T, Kaneda Y, Yorek MA, Beebe D, Oates PJ, Hammes HP, Giardino I, and Brownlee M. 2000. Normalizing mitochondrial superoxide production blocks three pathways of hyperglycaemic damage. Nature 404:787-790. 10.1038/35008121

Roskoski R, Jr. 2008. VEGF receptor protein-tyrosine kinases: structure and regulation. Biochem Biophys Res Commun 375:287-291. 10.1016/j.bbrc.2008.07.121

Royet J, Gupta D, and Dziarski R. 2011. Peptidoglycan recognition proteins: modulators of the microbiome and inflammation. Nat Rev Immunol 11:837-851. 10.1038/nri3089

Sanchez AP, and Sharma K. 2009. Transcription factors in the pathogenesis of diabetic nephropathy. Expert Rev Mol Med 11:e13. 10.1017/S1462399409001057

Sarkar K, Fox-Talbot K, Steenbergen C, Bosch-Marce M, and Semenza GL. 2009. Adenoviral transfer of HIF-1alpha enhances vascular responses to critical limb ischemia in diabetic mice. Proc Natl Acad Sci U S A 106:1876918774. 10.1073/pnas.0910561106

Schratzberger P, Walter DH, Rittig K, Bahlmann FH, Pola R, Curry C, Silver M, Krainin JG, Weinberg DH, Ropper AH, and Isner JM. 2001. Reversal of experimental diabetic neuropathy by VEGF gene transfer. J Clin Invest 107:1083-1092. 10.1172/JCI12188

Seshadri Sundararajan V, Gabere MN, Pretorius A, Adam S, Christoffels A, Lehvaslaiho M, Archer JA, and Bajic VB. 2012. DAMPD: a manually curated antimicrobial peptide database. Nucleic Acids Res 40:D1108-1112. 10.1093/nar/gkr1063

Soneja A, Drews M, and Malinski T. 2005. Role of nitric oxide, nitroxidative and oxidative stress in wound healing. Pharmacol Rep 57 Suppl:108-119.

Srikanth S, and Deedwania P. 2011. Primary and secondary prevention strategy for cardiovascular disease in diabetes mellitus. Cardiol Clin 29:47-70. 10.1016/j.ccl.2010.11.004

Suryavanshi SV, and Kulkarni YA. 2017. NF-kappabeta: A Potential Target in the Management of Vascular Complications of Diabetes. Front Pharmacol 8:798. 10.3389/fphar.2017.00798

Tak PP, and Firestein GS. 2001. NF-kappaB: a key role in inflammatory diseases. J Clin Invest 107:7-11. $10.1172 / \mathrm{JCI} 11830$

Tchaikovski V, Olieslagers S, Bohmer FD, and Waltenberger J. 2009. Diabetes mellitus activates signal transduction pathways resulting in vascular endothelial growth factor resistance of human monocytes. Circulation 120:150-159. 10.1161/CIRCULATIONAHA.108.817528

Tsai PW, Cheng YL, Hsieh WP, and Lan CY. 2014. Responses of Candida albicans to the human antimicrobial peptide LL-37. J Microbiol 52:581-589. 10.1007/s12275-014-3630-2

Wullaert A, Bonnet MC, and Pasparakis M. 2011. NF-kappaB in the regulation of epithelial homeostasis and inflammation. Cell Res 21:146-158. 10.1038/cr.2010.175

Yuan Y, Das SK, and Li M. 2018. Vitamin D ameliorates impaired wound healing in streptozotocin-induced diabetic mice by suppressing NF-kappaB-mediated inflammatory genes. Biosci Rep 38. 10.1042/BSR20171294 
469

470

471

472

473

474

475

476

477

478

479

480

481

482

483

484

485

486

487

488

489

490

491

492

493

494

495

\section{Figure legends}

Figure 1. Features of granulation tissue. Representative images of granulation tissue sections. (A) Staining using Masson's trichrome of ischemic and non-ischemic wounds in diabetic mice (x400). (B) HE staining of ischemic and non-ischemic wounds in diabetic mice (x400). (C) HE staining of ischemic and non-ischemic wounds in diabetic mice (x1000). (D) Caspase-3 staining of ischemic and non-ischemic wounds in diabetic mice (x400). (E) Duration of wound healing.

Figure 2. Effect of the fusion protein on inflammatory cytokines in ischemic adductor muscles. Data shown are means $\pm \mathrm{SD}(\mathrm{n}=8)$. (A) TNF-a; (B) IL-6. ${ }^{*} P<0.05, * * P<0.01$ vs NONISCH; $\$ P<0.05$ vs ISCH.

Figure 3. Levels of proangiogenic factors in serum. (A) Bar chart displaying PDGF concentration in plasma; (B) Bar chart displaying VEGF concentration in plasma. Data shown are means $\pm \mathrm{SD}(\mathrm{n}=8) .{ }^{*} * P<0.01$ vs NONISCH; ${ }^{\$} P<0.05$ vs ISCH.

Figure 4. Histological analysis of adductor muscles. (A) Representative images of adductor muscle sections stained by HE (x400). (B) Representative images of adductor muscle sections stained by HE (x1000). (C) Representative images of adductor muscle sections stained for CD34 (x400). (D) Representative images of adductor muscle sections stained for PDGF (x400). (E) Representative images of adductor muscle sections stained for Caspase 3 (x400). (F) Quantification of vascular density. ${ }^{* *} P<0.01$ vs NONISCH; ${ }^{\$} P<0.05$ vs ISCH.

Figure 5. mRNA expression of angiogenic factors in adductor muscles. Bar charts displaying relative levels of mRNA of angiogenic factors. Data represent as means $\pm \mathrm{SD}(\mathrm{n}=8)$. $\beta$-Actin mRNA was used as the endogenous control. Relative levels of mRNA of: (A) PDGF; (B) VEGF; (C) FGF-2; (D) eNOS; (E) HIF-1a in adductor muscles of diabetic mice. $* P<0.05$, $* * P<0.01$ vs 
496 NONISCH; $\$ \$ P<0.01$ vs ISCH.

497

498

Figure 6. Effect of the fusion protein on PDGF and VEGF signaling pathways. Bar charts displaying relative protein levels. Data represent as means $\pm \operatorname{SD}(n=6)$. (A) Western blot showing PDGF signaling proteins. (B) Western blot showing VEGF signaling proteins. (C) Relative levels

of p-PDGFR; (D) Relative levels of p-VEGFR. (E) Relative levels of PDGF. (F) Relative levels of VEGF. ${ }^{*} P<0.05,{ }^{* *} P<0.01$ vs NONISCH; ${ }^{\$} P<0.01$ vs ISCH.

503

Figure 7. Effect of the fusion protein on inflammation pathway. Bar charts displaying relative protein quantification. Data represent as means $\pm \mathrm{SD}(\mathrm{n}=6)$. (A) Western blot showing $\mathrm{p}-\mathrm{NF}-\mathrm{KB}$. (B) Western blot showing p-IKB a. (C) Relative levels of p- NF-KB. (D) Relative levels of p-IKB a. $* * P<0.01$ vs NONISCH; $\$ P<0.01$ vs ISCH. 
Figure 1

Features of granulation tissue.

Figure 1. Features of granulation tissue. Representative images of granulation tissue sections. (A) Staining using Masson's trichrome of ischemic and non-ischemic wounds in diabetic mice (x400). (B) HE staining of ischemic and non-ischemic wounds in diabetic mice (x400). (C) HE staining of ischemic and non-ischemic wounds in diabetic mice (x1000). (D)

Caspase- 3 staining of ischemic and non-ischemic wounds in diabetic mice (x400). Scale bar $=100 \mu \mathrm{m}$. (E) Duration of wound healing.
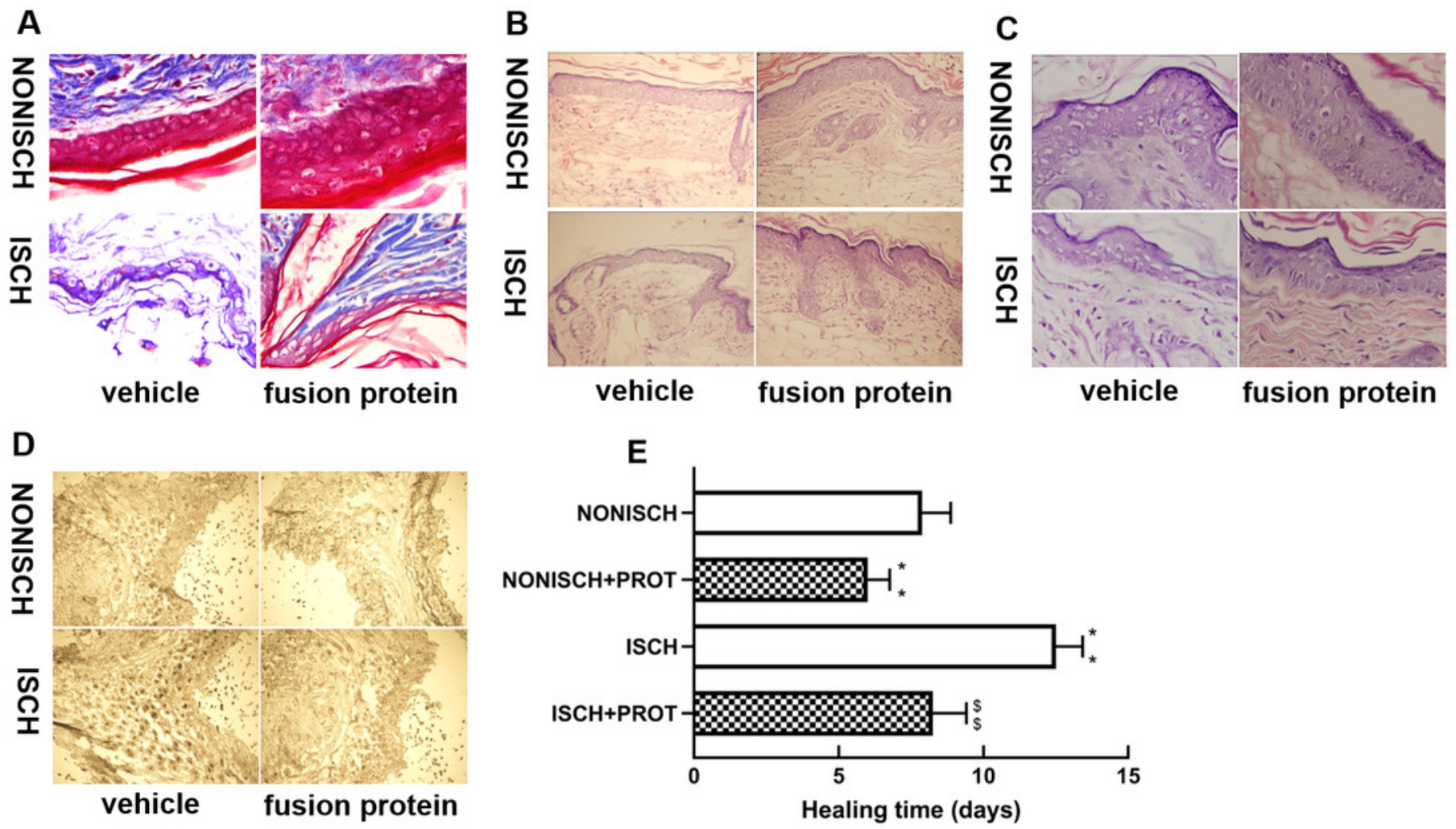
Figure 2

Effect of the fusion protein on inflammatory cytokines in ischemic adductor muscles.

Figure 2. Effect of the fusion protein on inflammatory cytokines in ischemic adductor muscles. Data shown are means $\pm S D(n=8)$. (A) TNF-a; (B) IL-6. $* P<0.05, * * P<$ 0.01 vs NONISCH; ${ }^{\$} P<0.05$ vs ISCH.

A

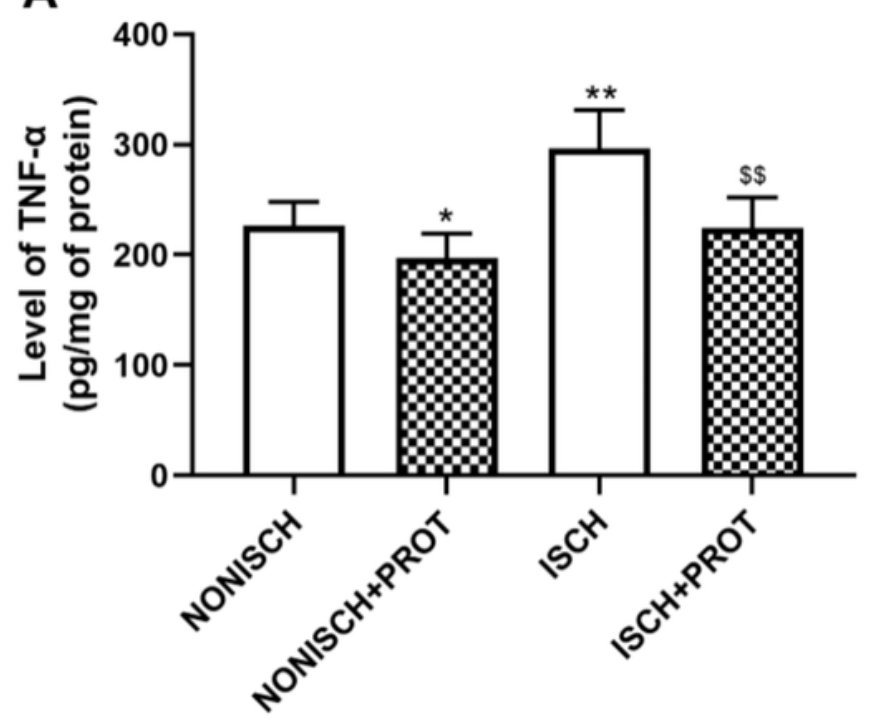

B

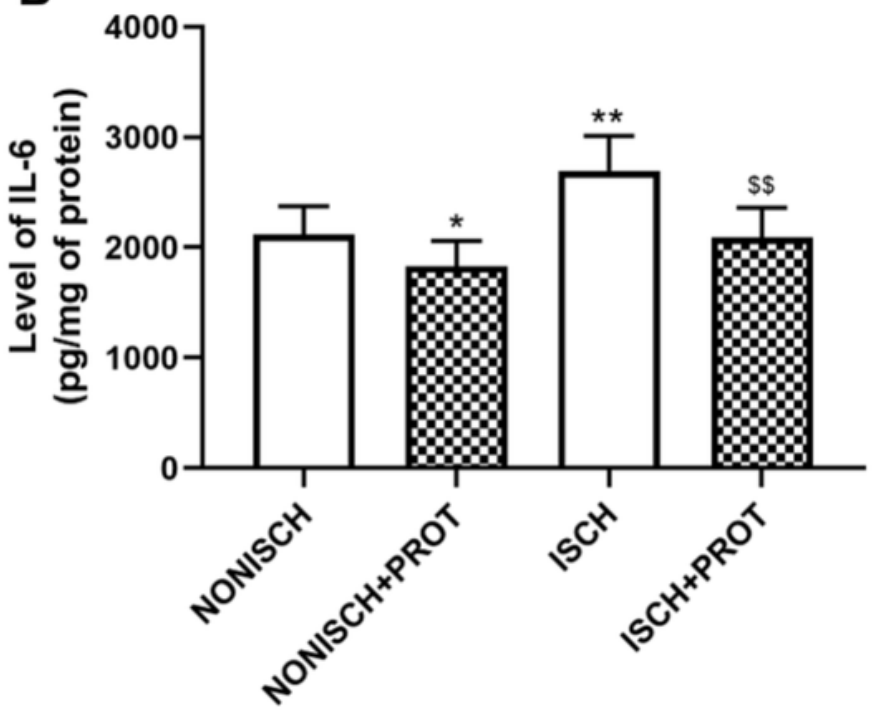


Figure 3

Levels of proangiogenic factors in serum.

Figure 3. Levels of proangiogenic factors in serum. (A) Bar chart displaying PDGF concentration in plasma; (B) Bar chart displaying VEGF concentration in plasma. Data shown are means $\pm \mathrm{SD}(\mathrm{n}=8) . * * P<0.01$ vs NONISCH; ${ }^{\$} P<0.05 \mathrm{vs} \mathrm{ISCH}$.

A

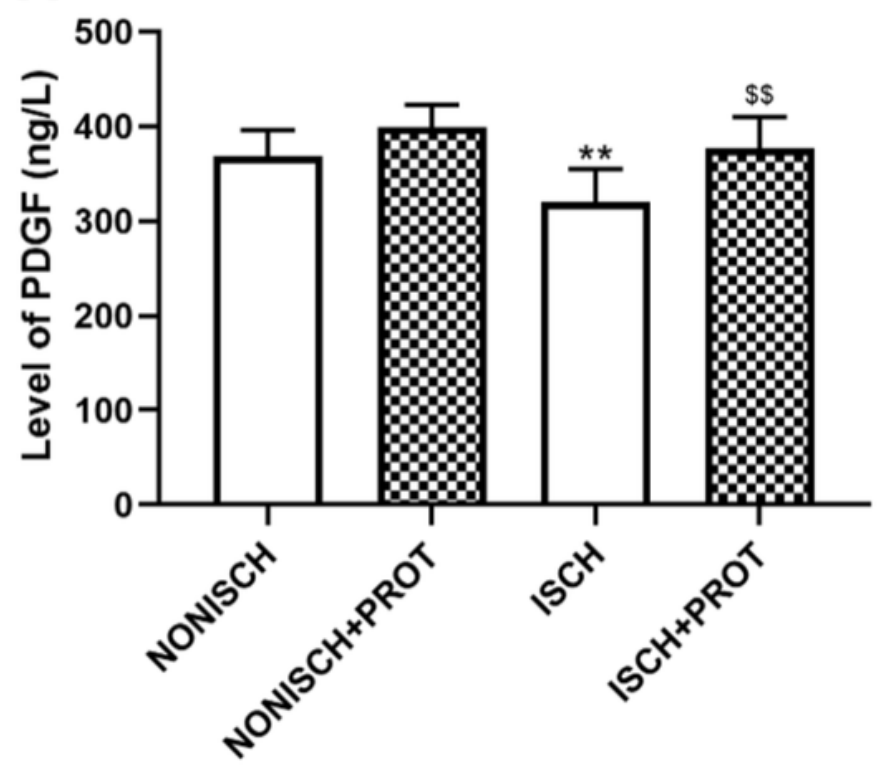

B

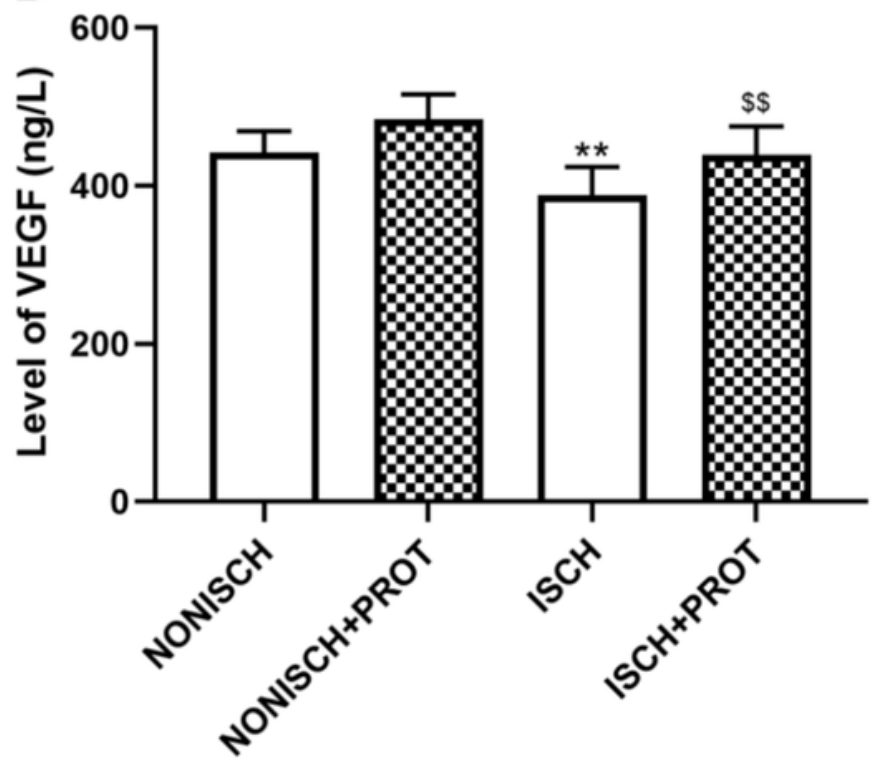




\section{Figure 4}

Histological analysis of ischemic adductor muscles.

Figure 4. Histological analysis of adductor muscles. (A) Representative images of adductor muscle sections stained by HE (x400). (B) Representative images of adductor muscle sections stained by HE (x1000). (C) Representative images of adductor muscle sections stained for CD34 (x400). (D) Representative images of adductor muscle sections stained for PDGF (x400). (E) Representative images of adductor muscle sections stained for Caspase $3(\mathrm{x} 400)$. (F) Quantification of vascular density. Scale bar $=100 \mu \mathrm{m} .{ }^{* * P}<0.01$ vs NONISCH; ${ }^{\$} P<0.05$ vs ISCH.
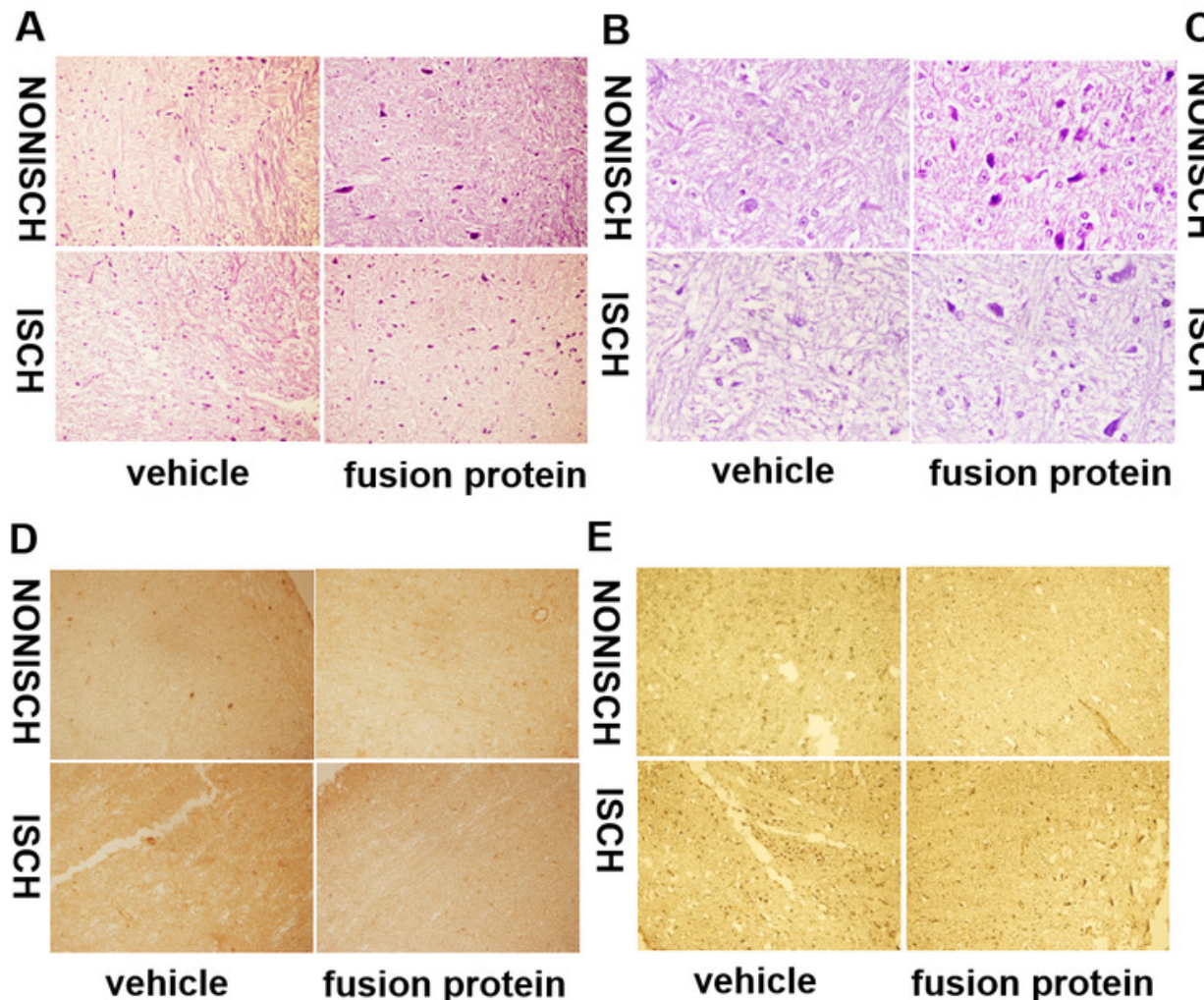

C
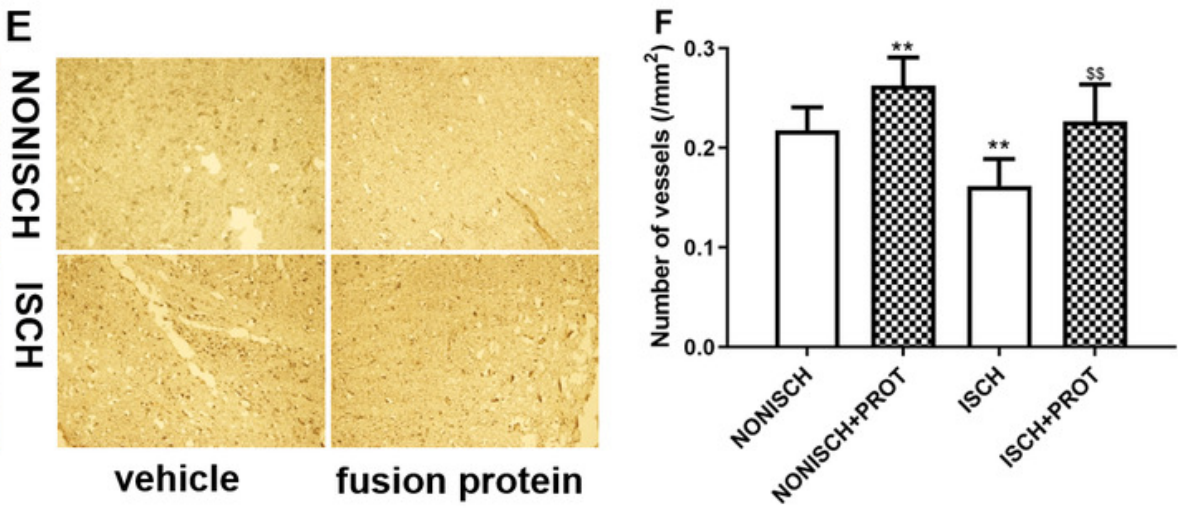
Figure 5

mRNA expression of angiogenic factors in adductor muscles.

Figure 5. mRNA expression of angiogenic factors in adductor muscles. Bar charts displaying relative levels of mRNA of angiogenic factors. Data represent as means \pm SD $(n=9)$. $\beta$-Actin mRNA was used as the endogenous control. Relative levels of mRNA of: $(A)$ PDGF; (B) VEGF; (C) FGF-2; (D) eNOS; (E) HIF-1a in adductor muscles of diabetic mice. *P < $0.05,{ }^{* *} P<0.01$ vs NONISCH; ${ }^{\$} P<0.01$ vs ISCH.
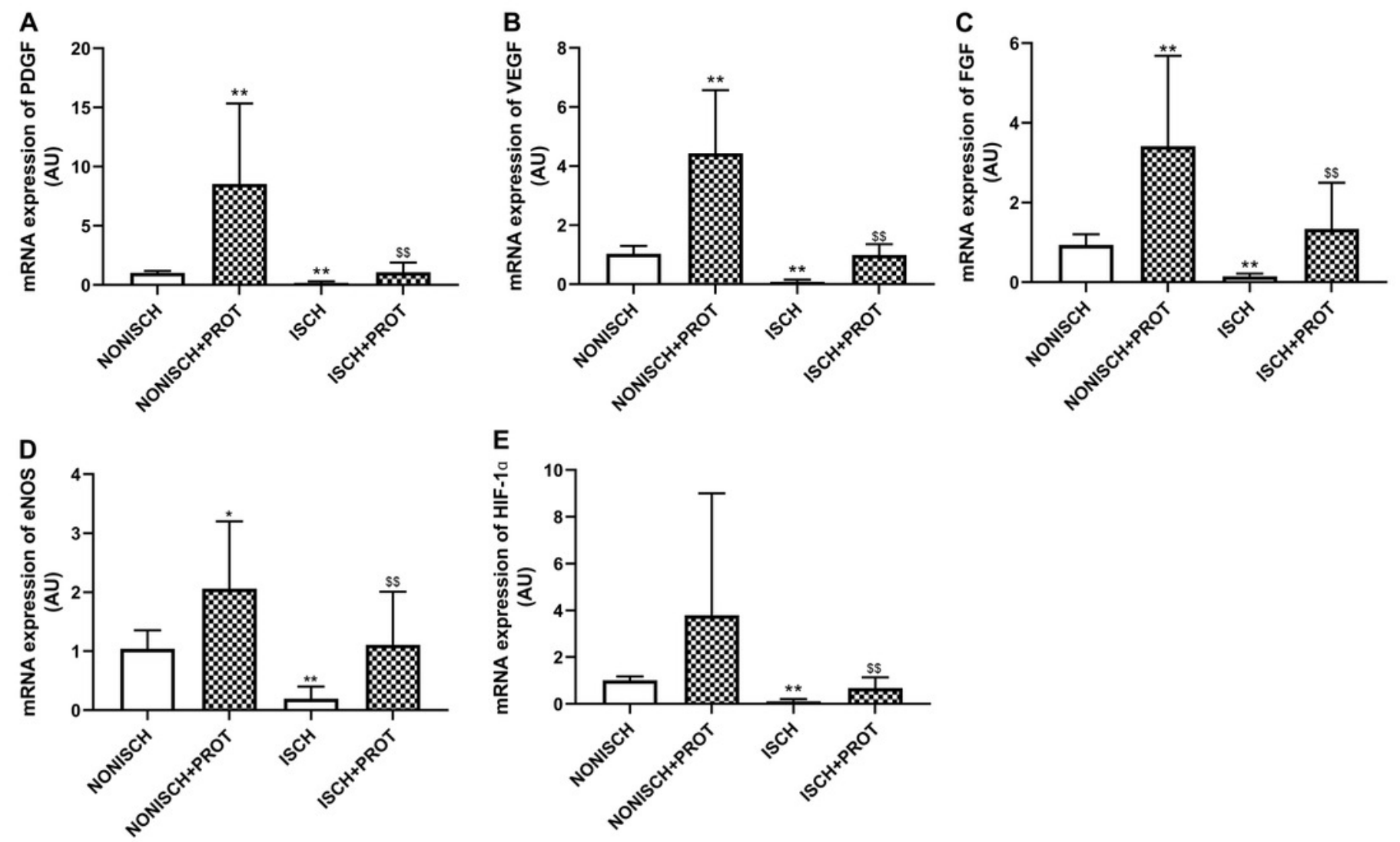
Figure 6

Effect of the fusion protein on PDGF and VEGF signaling pathways.

Figure 6. Effect of the fusion protein on PDGF and VEGF signaling pathways. Bar charts displaying relative protein levels. Data represent as means $\pm S D(n=6)$. (A) Western blot showing PDGF signaling proteins. (B) Western blot showing VEGF signaling proteins. (C) Relative levels of p-PDGFR; (D) Relative levels of p-VEGFR. (E) Relative levels of PDGF. (F) Relative levels of VEGF. $* P<0.05, * * P<0.01$ vs NONISCH; ${ }^{\$ \$} P<0.01$ vs ISCH.

A
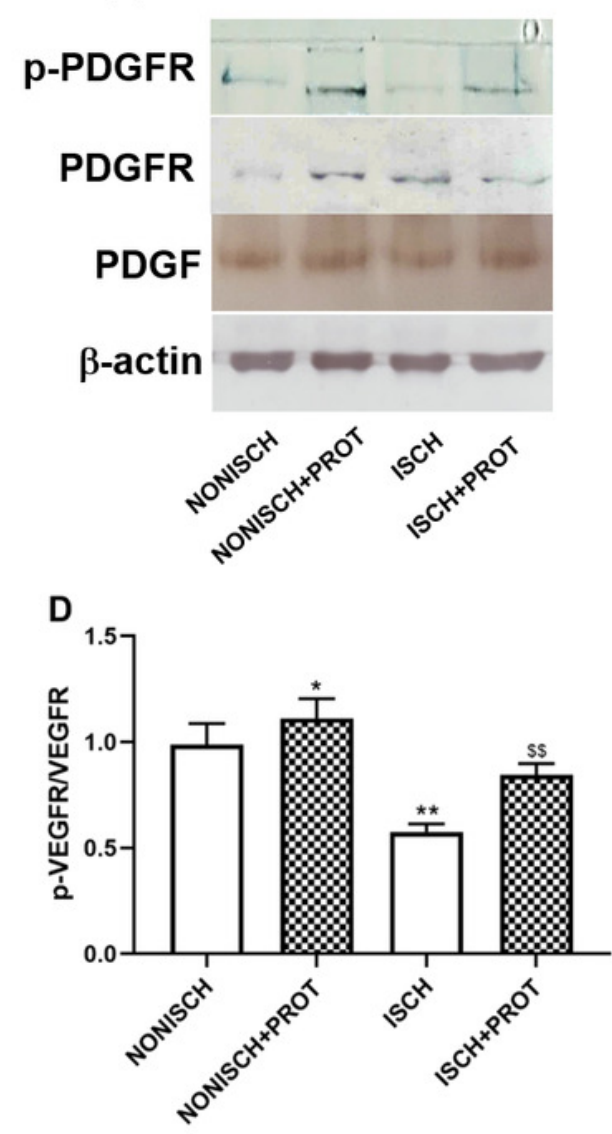

B

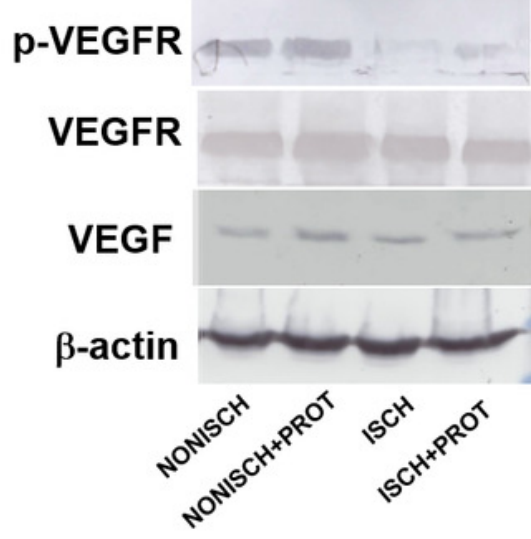

E

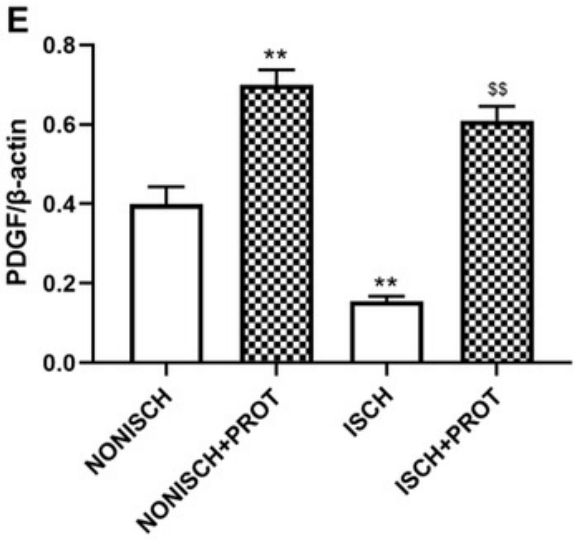

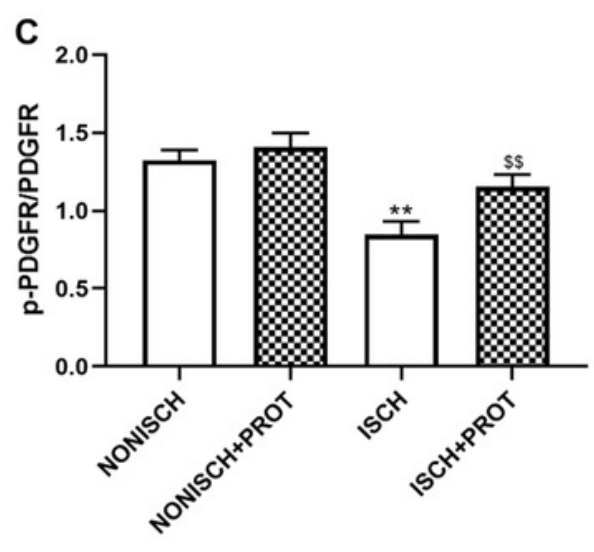

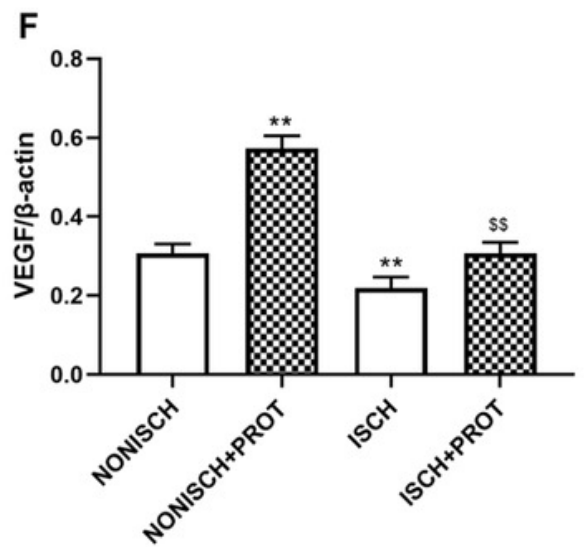


Figure 7

Effect of the fusion protein on inflammation pathway.

Figure 7. Effect of the fusion protein on inflammation pathway. Bar charts displaying relative protein quantification. Data represent as means $\pm S D(n=6)$. (A) Western blot showing p- NF-KB . (B) Western blot showing p-IKB a. (C) Relative levels of p- NF-KB. (D) Relative levels of p-IKB a. ${ }^{* * P}<0.01$ vs NONISCH; ${ }^{\$ \$} P<0.01$ vs ISCH.

A

p-NF-KB

NF-KB

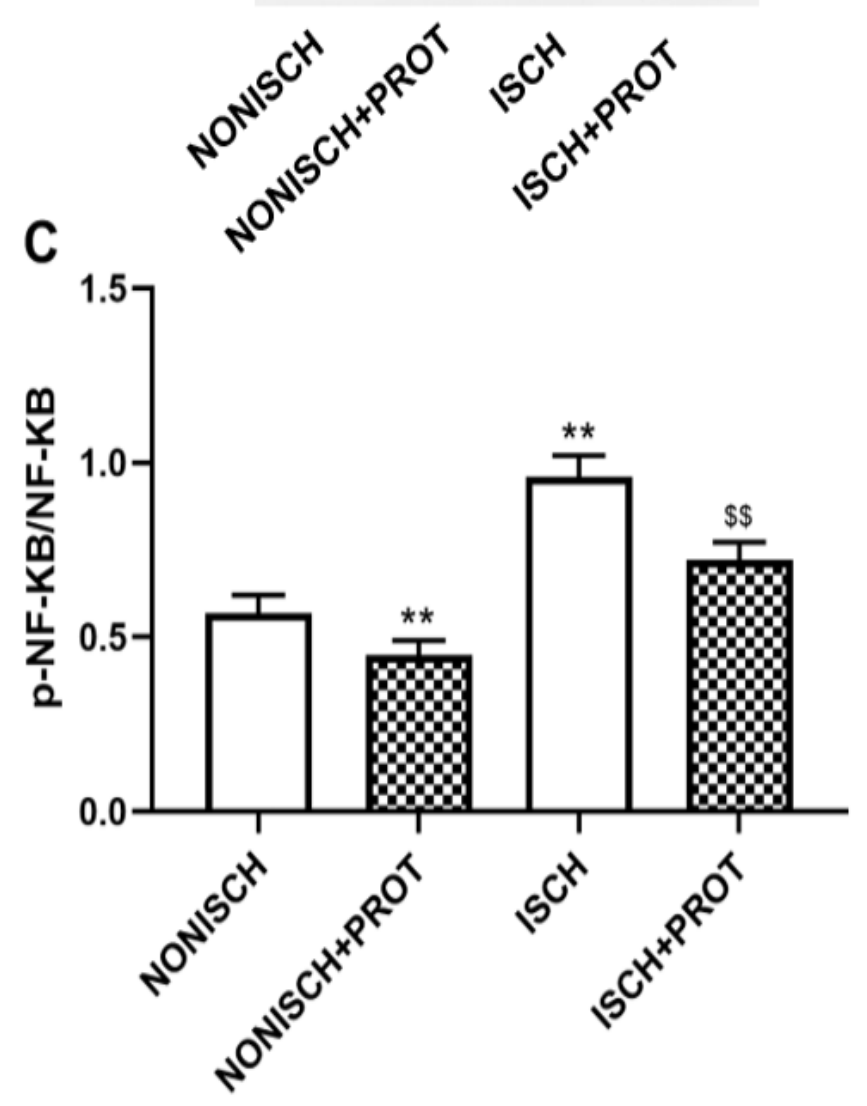

$\mathrm{p}-\mathrm{IKBa}$

D
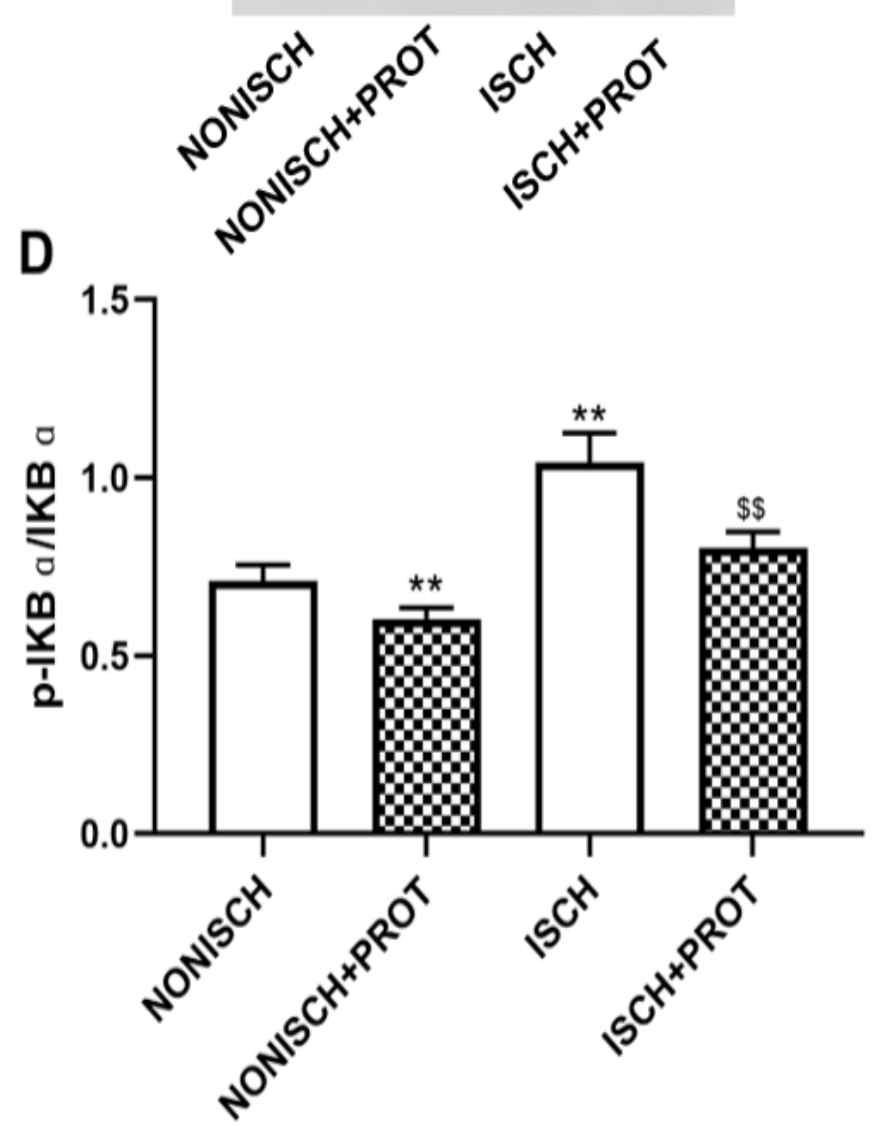